\section{ILLUSTRATIONS OF NEW OR RARE ANIMALS IN THE ZOOLOGICAL SOCIETY'S LIVING COLLECTION ${ }^{1}$}

\section{IV.}

8. THE White-nosed Saki (Pithecia albinasa).-The peculiar American monkeys which belong to the closely-allied genera Pithecia and Brachyurus of naturalists, and are generally known as "Sakis"-a name probably derived from some Indian term-are restricted to the forests of Guiana and Amazonia, and seem to have in the case of each species a very restricted geographical area of distribution, one of these monkeys not intruding within the limits of another. As regards the genus Brachyurus, which is little more than Pithecia with a shortened tail, Mr. W. A.[Forbes has lately shown this to

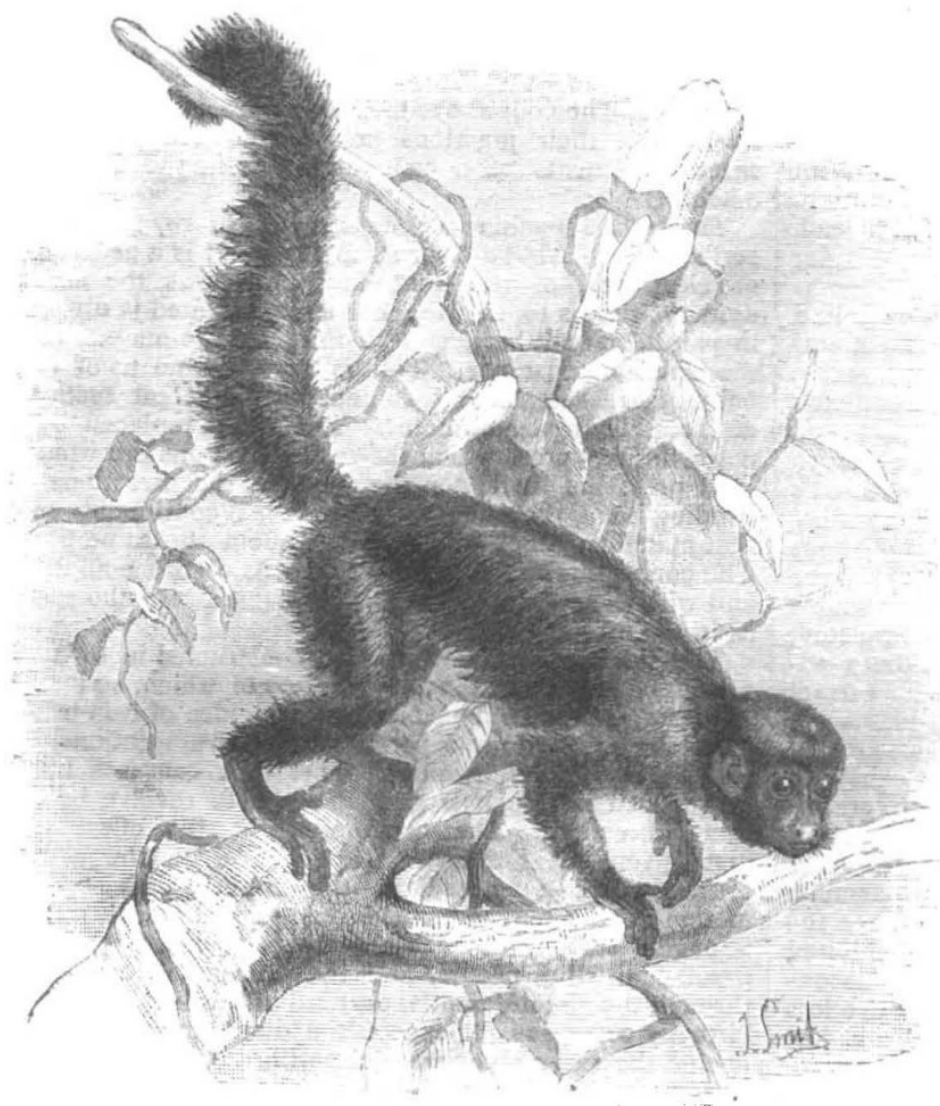

FIG. 8.-The White.nosed Saki.

be the case, in an article published in the Zoological Society's Proceedings, ${ }^{2}$ wherein, after describing the anatomy of Brachyurus rubicundus, he has given a map to illustrate the distribution of this and the two allied species of Brachyurus. Each of them is limited to a peculiar district of Amazonia, one $(B$. melanocephalus) to the forests of the Rio Negro, a second ( $B$. calvus) to those lying between the Putumayo and the Japurá, on the north bank of the Amazons, and the third ( $B$. rubicundus) to the district contained between the main stream and the Rio Ica.

In like manner the few particulars which have yet been recorded as to the exact localities of the Pithecia

1 Continued from vol. xxiii. p. 480

2 "On the External Characters and Anatomy of the Red Ouakari Monkey (Brachyurus rubicundus) ; with remarks on the other species of that Genus." By W. A. Forbes, B.A., F.L.S., Fellow of St. John's College, Cambridge, Prosector to the Society, $-F . Z$. S., 1880, p. 627 . seem to tend to similar conclusions. Although we must suppose them, in obedience to the laws of descent, to have originated in common ancestors, they now occupy restricted areas cut off from one another, and in some cases rather widely separated. Why, in this as in similar cases, the form should have ceased to exist in the intermediate districts, is a subject on which it is at present difficult even to offer a conjecture.

The Pithecice are easily divisible into two sectionsone embracing the curly-haired species, such as $P$. leucocephala; $P$. monachus, and their allies, and the other the smooth-haired forms, such as $P$. satanas (commonly called by the dealers the Jew-Monkey), and $P$. chiropotes. The White-nosed Saki, of which a figure is herewith given (Fig. 8), belongs to the latter group, and is one of the rarest and least known of the South American monkeys. A single example of it was obtained by the French collector Deville, on the Upper Amazons, during his descent of that river in company with de Castlenau's celebrated expedition, and is now in the Paris Museum. It was first described by Deville and Isidore Geoffrey St. Hilaire jointly, in 1848 , and subsequently figured in the "Zoologie" of Castlenau's expedition, but the exact locality where it was procured was unfortunately left unrecorded.

The example of this monkey, lately living in the Zoological Society's collection, was purchased of a dealer in January last. It is uniformly, but rather sparingly covered with black hairs. The nose is broadly naked, and of a bright fleshy red, but shows a few white hairs between the nostrils, which are sufficient to justify its scientific name. The long hairs on the head fall on both sides of the head and over the front. The length of the body is about fifteen inches, of the tail eighteen inches. The latter organ, although clothed with elongated hairs, appears to be slightly prehensile. The specimen is of the female sex, apparently not fully adult.

9. The Mountain Nestor or Kea (Nestor notabilis). - Whatever may have formerly been thought to the contrary, there can be now no doubt that animals are continually changing their habits in order to suit themselves to the altered circumstances of their existence. A very familiar instance of this is that of the common swallow, which, in Europe at least, usually builds its nest in chimneys. Before chimneys were invented it must obviously have affixed its nest to some other chimney-like structure-probably to the inside of a hollow tree. But a much more striking and less laudable change of habit has of late years taken place in a New Zealand bird, of which we berewith give an illustration (Fig. 9). Parrots, though varying much in the details of their diet, are generally considered to be altogether frugivorous. Fruit and seeds, and in certain special cases moss and honey, are, no doubt, their proper food. But since the introduction of the domestic sheep into New Zealand the Mountain Nestor, which was previously content with a modest repast of an entirely vegetable character, has developed a taste for mutton. Many instances have now been recorded of this bird attacking not only sick and dying sheep, but, it is alleged, even those that are strong and healthy, though we should hardly suppose that this parrot exists anywhere in sufficient numbers to be likely to do the flock-masters any serious injury.

${ }^{x}$ Frcm the interesting article by Mr. Potts on the habits of this parrot just 
The individual of this species now in the Regent's $\mid$ Dr. Hector as follows:-_ "Perching itself on the sheep's Park collection, from which the drawing has been taken, head or other offal, the bird proceeds to tear off the skin was transmitted as a present to the Society by Dr. A. de Lautour of Otago, New Zealand, along with the subjoined particulars concerning it, contained in a letter addressed to the secretary :-

"I have the pleasure of informing you that I am sending home an example of the Kea (Nestor notabilis), or Mountain Parrot, a bird celebrated, or rather notorious for its sheep-destroying proclivities.

"Many abler pens than mine have already written about their habits; but I was fortunate enough to be perhaps the first to send home a specimen of their work in the shape of the colon and lumbar vertebræ of a sheep, in which colotomy had been performed by one of these birds.

"This specimen was shown at a meeting of the Pathological Society by my friend and former master, Mr. John Wood, F.R.S., and is now in the Museum of the Royal College of Surgeons of England.

"The bird which I am now sending home has been in my possession for nearly two years. It was caught in the act of attacking some sheep which a shepherd was bringing down off the tops of some ranges in the back country. He luckily streceeded in knocking it over with a stone, cut its wings, and brought his captive down. In effecting the capture the shepherd suffered considerable loss as to his trousers and other garments, and not a little injury in scratches from its formidable beak and claws. These

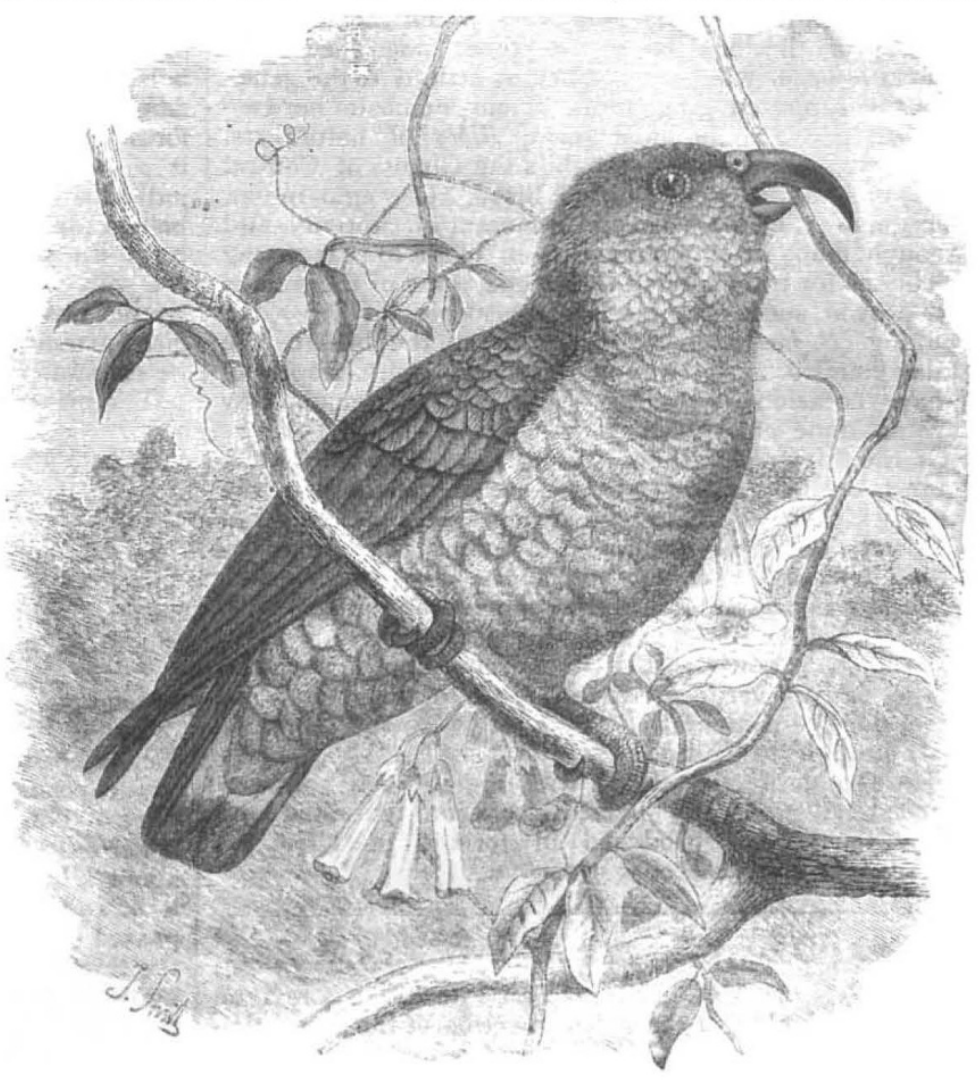

Fig. 9.-The Mountain Nestor.

same scratches had not entirely healed when he came | and flesh, devouring it piecemealafier the manner of a hawk, down here under my care some ten days later, suffering from a broken leg (this by the way was not done by the Kea).

"While I have had the Kea, his diet has consisted mainly of mutton, raw; he does not care for cooked meat, but wil: take it if very hungry. Occa. sionally he will take beef, and he is fond of pork. Popularly he is said to prefer fat, but in confinement he chooses the lean and leaves the fat; he does not care for biscuit, but he likes the seed of the sow-thistle."

Again, in his excellent work on the birds of New Zealand, Dr. Buller tells us that the "penchant for raw flesh exhibited by this parrot in its wild state is very remarkable. Those that frequent the sheepstations appear to live almost exclusively on flesh. They claim the sheeps' heads that are thrown out from the slaughter-shed, and pick them perfectly clean, leaving nothing but the bones." An eye-witness has described this operation to

published (in the Zoologist of the present month), it would seem, however, that the losses sustained by the attacks of the Kea are in some cases very serious.

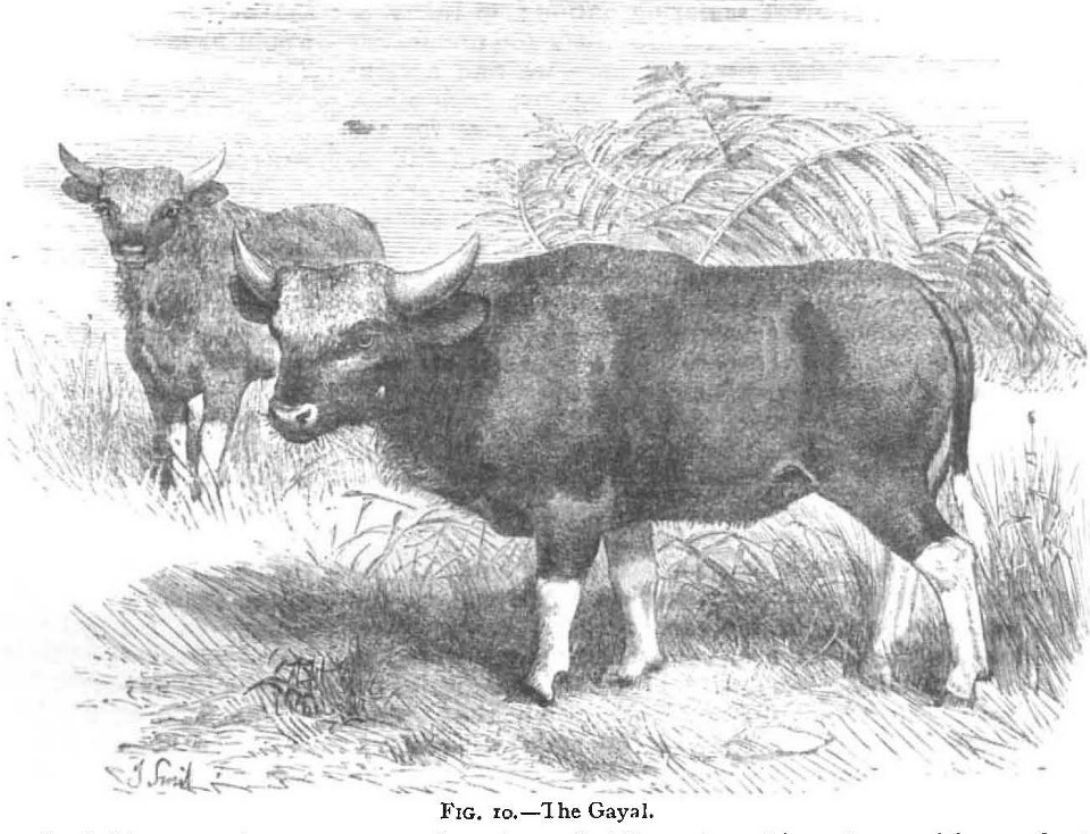

FIG. xo.-The Gayal. or at other times holding the object down with one foot, and with the other grasping the portion it was eating, after the fashion of ordinary parrots. The plan usually adopted on the stations for alluring this bird is to expose a fresh 
sheepskin on the roof of a hut ; and whilst it is engaged in tearing up the bait it is easily approached and snared." Io. The Gayal (Bibos frontalis). - In the mountainous districts of the oriental region three fine species of wild cattle occur which do not belong strictly to the genus Bos-the supposed progenitors of our domestic herdsbut to a slightly modified form, Bibos of naturalists. One of these - the Gaur-inhabits the Ghauts of Central India, and is the well-known "Bison" of Anglo-Indian sportsmen. The Gaur is very intolerant of captivity, and although many attempts have been made to rear young specimens for transmission to Europe, none of them have ever proved successful. A second species of Bibos, the Bantang ( $B$. javanicus), is found only in the hills of the Malay countries. It is more tractable, and examples of it have occasionally reached Europe alive, though they have not done well in this country.

Of the third Bibos, the Gayal (B. frontalis), we give a figure taken from a fine pair of these animals now in the Zoological Society's Gardens, which were received from the sister Zoological Society of Calcutta. The Gayal, as Jerdon tells us, in a state of nature inhabits the hilly tracts to the east of the Brahmapootra and at the head of the Valley of Assam, extending into the Mishmi Hills and adjacent ranges. It is caught and kept in captivity by the natives very extensively, and to this fact is no doubt due the comparative ease with which specimens of it are brought to Europe.

The Gayal breeds readily with the different forms of Domestic Ox. Many hybrids between the Zebu and Gayal have been produced in former years in the Zoological Society's Menagerie.

\section{SHIPBUILDING A THOUSAND YEARS AGO}

$M$ R. COLIN ARCHER read an interesting paper on $\mathrm{M}$ this subject at the recent meeting of the Institution of Naval Architects, as also at the York meeting of the British Association.

It is a well-known historical fact that as far back as the early part of the Middle Ages, the inhabitants of Scandinavia were a great seafaring nation: in many of the great battles fought between the chiefs and pretenders of that period-and they were not few-we find several hundreds of large war-ships ranged against each other. It seems to have been quite a common practice for the young chiefs, in order to relieve the monotony of life on shore, or to escape the consequences of some lawless act, to equip one or more ships, manned by their retainers, and to launch forth in quest of adventure, plunder, or "the bubble reputation." And these excursions were not always confined to home waters; they were frequently extended not only to the coast countries of the north of Europe, but also to the shores of the Mediterranean. Iceland was discovered about the middle of the ninth century by Norwegian adventurers, and there are good grounds for believing that an expedition starting from Iceland landed and established a colony in the present New England States nearly 500 years before Columbus lived.

But the descriptions which the old Sagas afford of the vessels in which these expeditions were undertaken, and these battles were fought, are very meagre. It was therefore looked upon as an event of great interest when, on excavating a large grave-mound near the entrance to Christiania Fjord, a ship, evidently from the Viking period, was discovered in a wonderful state of preservation. There is reason to believe that this ship, although comparatively small, does not differ materially in her manner of construction or in shape from the more powerful war-ships, or from those used for long voyages. She is probably a true model of the ships which carried Rollo and his brave followers to the coast of Normandy; and it may therefore be assumed that a brief description of her, as she now appears from a shipbuilder's point of view, may not be without interest.

It was not to be expected that a delicate structure such as this Viking ship could remain for eight or ten centuries buried many yards under ground without sustaining some damage, or that she should perfectly retain her original form. It is rather a matter of surprise that the damage is so small as it is. Thanks to careful handling and a judicious arrangement of supports, there is reason to believe that, apart from local strains and contortions of form, the hull as it now stands represents very closely the ship as she appeared when put into the ground. Mr. Archer has taken off her lines with as much accuracy as circumstances would permit, and, referring to these lines, he explains the chief peculiarities of the construction.

The principal dimensions are :-

$\begin{array}{lllrrr}\text { Length between the rabbets at gunwale } & \ldots & \ldots & \text { Feet. } & \text { Inches. } \\ \text { Breadth, extreme } \ldots & \ldots & \ldots 7 & \text { II } \\ \text { Depth from top of keel to gunwale amidships } & \ldots & 5 & 9\end{array}$

The vessel is clinker built, and the material all oak. There are sixteen strakes of outside planking, the ordinary thickness 1 inch, average breadth amidships $9 \frac{1}{2}$ inches, including I inch land. The lengths vary from 8 to 24 feet. The scantling is not, however, uniform throughout; thus the tenth plank from the keel is about 8 inches broad and $I_{\frac{3}{4}}$ inches thick, and forms a shelf for the beam-ends. The fourteenth plank from the keel, or third from the top, is about Io inches broad and $I \frac{1}{4}$ inch thick. This plank, which we may call the "main wale," is perforated with holes for the oars, sixteen on each side, about 4 inches diameter, and provided with a slit at the after and upper edge to allow the blades of the oars to be passed through from inboard. The two upper strakes are the thinnest of all, being scarcely more than $\frac{3}{4}$ inch. The gunwale, 3 inches by $4 \frac{1}{2}$ inches, is placed in the usual manner insicle the top strake. The boards are throughout united to each other by iron rivets about the thickness of an ordinary 3 inch spike, spaced from 6 to 8 inches, with large flat heads $I$ inch diameter. The riveting plates are square or nearly so, $\frac{3}{4}$ inch. The nails are driven from the outside, except near the ends, where riveting inside would have been difficult from the sharpness of the vessel. The nails are here driven from the inside and riveted outside. The garboard strake is fastened to the keel with rivets of the same kind as those used for joining the strakes with each other.

The keel is of a peculiar shape; it is about 14 inches deep, of which II inches are belcw the rabbet, $4 \frac{1}{2}$ inches thick at the lower edge, and only 3 inches at the rabbet. The top of the keel is 7 inches broad, thus affording a large surface for the garboard strake, besides combining strength with lightness. Possibly also the increased thickness of the lower edge may have been adopted to improve weatherliness under sail. It is difficult to say where the keel ends and the stem and sternpost begin, as these run into each other with a very gentle sweep; but the piece of wood which may be called the keel proper is 57 feet long; to it are joined a short forefoot and heel piece by short vertical scarfs secured by double rows of rivets. These pieces again are fitted in a similar manner to the stem and stern-post. The posts are sided 3 inches, chamfered to 2 inches outside edge. They are $15 \frac{1}{2}$ inches broad outside the rabbet just above the scarf, decreasing in breadth upwards.

The framing of the bottom consists of grown floors extended in one piece from shelf to shelf. The average spacing in the body of the vessel is about 3 feet 3 inches from centre to centre, greater at the ends: there are nineteen frames in all. The floors are neatly finished, of a shape which combines strength with lightness and elasticity. The lower surface has a flat projection in which are holes for receiving the fastenings for the plank. The way these fastenings are managed is very peculiar. The 